\title{
ÚVODNÍ POZNÁMKA
}

Svazek AUC, který předkládáme čtenáři, je výsledkem práce oddělení vědeckého komunismu a sociálního výzkumu katedry marxisticko-leninské filozofie, jež souvisí s aplikací závěrů profilové analýzy studijního oboru sociologie, zejména té její části, $\checkmark$ níž se zdůrazňuje nezbytnost orientace na aktuální problémy současnosti, na sepětí sociologické práce s potřebami společnosti. Majíli se tyto požadavky promítnout do výuky, je pochopitelně nezbytné konkretizovat studijní profil posluchačů sociologie. Orientace na sociologii prưmyslu se zdá nejoptimálnější variantou takové konkretizace, což ostatně dokládají i zkušenosti sovětské a vyučovací a studijní plány polské a bulharské.

Sborník je uveden obecněji koncipovanou studií o krizi sociologie $\mathrm{v}$ průmyslově vyspělých kapitalistických zemích, na niž navazuje v implicitní polemice úvaha a informace o sovětských průmyslově sociologických koncepcích, jež jsou situovány do širokého rámce problematiky vědeckotechnické revoluce. Následující studie o malé skupině $v$ průmyslové organizaci má ráz poněkud speciálnější a sleduje cíle kritické i informativní. Konkrétním příspěvkem $\mathrm{k}$ analýze jednoho aspektu průmyslově sociologické problematiky je studie o profesionální životní dráze. V informacích pak čtenár̆ najde úvahu o sporech kolem proslulé dichotomie formální a neformální organizace a struktury.

Pracoviště, které předkládá tento sborník, je pracovištěm pedagogickým - odtud i převaha teoretického zájmu. Sborník je prvním krokem $\mathrm{k}$ naplnění požadavku konkrétní problémové orientace a prvním prípravným aktem $\mathrm{k}$ realizaci nové koncepce výuky sociologie na filozofické fakultè. 